\title{
Educational Beliefs and Passion among Preservice Teachers: A Comparative Statistical Analysis
}

\author{
Low Suet Fin ${ }^{1 *}$, Zahari Ishak ${ }^{2}$ \\ 1. Road User Behavioural Change Research Centre (RUBC), Malaysian Institute of Road Safety Research (MIROS), ASEAN Road Safe- \\ ty Centre, Lot 125-135, Jalan TKS 1, Taman Kajang Sentral, 43000 Kajang, Selangor D.E., Malaysia \\ 2. Department of Educational Psychology and Counselling, Faculty of Education, University of Malaya, 50603 Kuala Lumpur, Malaysia
}

How to cite this paper: Fin, L. S., \& Ishak Z. (2018). Educational Beliefs and Passion among Preservice Teachers: A Comparative Statistical Analysis. The Educational Review, USA, 2(5), 281-288.

http://dx.doi.org/10.26855/er.2018.05.002

Corresponding author: Low Suet Fin, Ph.D., Director, Road User Behavioural Change Research Centre (RUBC), Malaysian Institute of Road Safety Research (MIROS), ASEAN Road Safety Centre, Lot 125-135, Jalan TKS 1, Taman Kajang Sentral,43000 Kajang, Selangor D.E., Malaysia.

\begin{abstract}
The objective of this study was to identify the differences for the sub-constructs of educational beliefs and passion for teaching among 409 preservice teachers from Malaysia and China. Results demonstrated that Malaysian preservice teachers scored the highest mean for traditionalism whereas the Chinese preservice teachers obtained the highest mean for romanticism. As for passion, the Malaysian and Chinese preservice teachers reported the highest mean in harmonious passion. Findings reported as for educational beliefs, the mean of two countries in their traditionalism and progressivism was significantly different. Preservice teachers from Malaysia reported higher mean than those from China in both cases. Regarding passion for teaching, the differences were only found in obsessive passion where Malaysian pre-service teachers reported the higher mean.
\end{abstract}

\section{Keywords}

Educational Beliefs, Passion, PreService Teachers, Traditionalism, Progressivism, Romanticism, Harmonious Passion and Obsessive Passion

\section{Introduction}

Education quality has been the focus of discussion to many educationists over the world. This is because quality education nurtures human talent and creativity, thereby contributing to the personal and professional development of the individual, as well as to social, cultural, economic, political and environmental development of society at large (Education for All, 2016). However, one of the vital elements in the success of providing our generation with quality education depends on the implementer of the education process, namely the teachers. In order to achieve the vision of quality education, we must have quality teachers who can perform quality and effective teaching to the students (Andrew \& Schwab, 1995; Bents \& Bents, 1990). According to Lin, Xie, Jeng, and Huang (2010), teacher quality is defined as teachers engaging in education tasks, with certain characteristics, and being able qualified to conduct teaching activities, arousing students' interest in learning, and enhancing students' learning achievements. It implies that beside having good qualification, teachers should possess certain characteristics which will enable them to produce effective classroom teaching. Educational beliefs and passion in teaching are among those important characteristics.

Teachers' educational beliefs will determine how they deliver the knowledge or conduct their teaching. Kagan (1992) defined teacher beliefs as "tacit and often unconsciously held assumptions about students, classrooms, and the academic material to be taught". These beliefs which are embedded in their cultural background, gender differences and previous 
personal experience will drive or motivate someone to behave in a certain pattern (Sang et al., 2012). Basically, the belief that teachers hold will shape their professional practice. According to Clark (1988), these beliefs were formed before individuals enrolled into an education major or before they involved in teaching practices. Progressivism is a type of educational belief held by teachers. Progressive teachers' role are as facilitators and they teach based on the needs, interests and developmental stage of the child; it means teaching students the skills they need to learn any subject. These teachers focus on discovery and self-directed methodologies by engaging students actively in the class (Labaree, 2005). Traditional teachers' methodologies are teacher-centered with highly "teacher-dominated interaction" (Broughton et al., 1994). They believed that if students are present in the lesson and listen to the teacher's explanations and examples in a controlled learning environment, students will be able to use the knowledge (Boumová, 2008). Romanticism emphasized on the education of the whole person with the focus on emotions and encouraged self-expression and self-actualization (Noddings, 2007). Romantic teacher's role is to be a facilitator of students' learning experience and provide suitable learning environment to them. They also allow students what they want to learn and allow them to choose their preferred way of learning.

Villarroel (2015) stated that passion is globally recognized as one of the greatest assets when anybody has the opportunity to lead, teach or influence the lives of others. A passionate teacher is to be someone in love with a field of knowledge, deeply stirred by issues and ideas that challenge our world, drawn to the dilemmas and potentials of the young people who come into class each day (Fried, 2001). Mart (2013) found that passion can motivate and inspire teachers besides affecting teacher performance. It drives the teachers for a better student accomplishment. Harmonious passion is defined as a "strong psychological investment in a passionate activity that has been autonomously internalized within the identity" (Fernet et al., 2014) motivating an individual to take part in their preferred activities. Obsessive passion, on the other hand, is autonomously internalized into one's identity where the individual cannot help but have to engage with the activities and in turn, stress the person out (Fernet et al., 2014; Vallerand et al., 2003).

Review on literature demonstrated many factors could have contributed to the forming of educational beliefs, namely personal experience, beliefs, value (Clark, 1988), perceptions towards the importance of pedagogy training (Su, 2012), what individual's experienced and values held in life (Yero, 2002). On the other hand, Su (2012) in her literature review categorized the factors shaping one's educational beliefs into three themes: (1) personal factors, (2) environmental factors, and (3) duty-related factors. Little is known about the antecedents or determinants of passion among teachers. Researchers were trying to study the relationship of work-related variables including job autonomy, interpersonal outcomes, and personal characteristics among workers. Passion has been found to be related to teachers' job satisfaction, positive and negative affect, psychological well-being and risks of burning out (Carbonneau et al., 2008; Vallerand et al., 2010). The main objective of this study is to identify the types of educational beliefs and passion for teaching hold by Malaysian and Chinese pre-service teachers. Besides that, it is also aimed to compare educational beliefs and passion for teaching between pre-service teachers of both countries and to identify the significant differences between them.

\section{Methodology}

This is a descriptive cross-sectional quantitative study where data were only collected once at a specific point of time. Two stage sampling comprising purposeful random sampling and simple random sampling was applied to gather the data of the study. During the first stage, all the public universities and institutes of teacher education which provide training to TESL and Mandarin preservice teachers in Malaysia and China have been identified. During the second stage, a public university located in Shanghai, China and a few public universities and institutes of teacher education in Malaysia have been selected due to time and financial constraints. The total samples are 409 final year TESL and Mandarin preservice 
teachers. Some 88 participants have been selected randomly from a public university in Shanghai, and a total of 321 samples are from 5 public universities and 5 institutes of teacher education in Malaysia. Self-administered questionnaire comprises of Educational Beliefs questionnaire (Silvernail, 1992) and Passion scale (Vallerand et al., 2003) were used to collect data on demographics, educational beliefs and passion for teaching.

\section{Results of Research}

Instrument reliability was assessed using estimates of internal consistency (Cronbach alpha). The cut-off value for Cronbach alpha is .70 and above (Hinton et al., 2004). Data were analysed based on SPSS (Statistical Packages for the Social Sciences) to generate descriptive statistics of the participants and to achieve the objectives of this study. The instrument has achieved acceptable reliability as the value of Cronbach alpha is .86 for educational beliefs and .89 for passion for teaching (Hinton et al., 2004).

Table 1. Mean and standard deviation educational beliefs and passion for teaching between pre-service teachers from Malaysia and China.

\begin{tabular}{|c|c|c|c|c|c|c|c|c|}
\hline \multirow[b]{2}{*}{ Construct } & \multicolumn{4}{|l|}{ Malaysia } & \multicolumn{4}{|l|}{ China } \\
\hline & Minimum & Maximum & Mean & $\begin{array}{l}\text { Standard } \\
\text { deviation }\end{array}$ & Minimum & Maximum & Mean & $\begin{array}{l}\text { Standard } \\
\text { deviation }\end{array}$ \\
\hline Trad & 10.00 & 40.00 & 31.12 & 4.36 & 19.00 & 33.00 & 27.17 & 3.33 \\
\hline Prog & 6.00 & 30.00 & 24.38 & 3.23 & 16.00 & 28.00 & 22.17 & 2.39 \\
\hline Rom & 7.00 & 35.00 & 27.53 & 4.15 & 18.00 & 34.00 & 27.39 & 3.29 \\
\hline $\mathrm{PC}$ & 4.00 & 20.00 & 15.70 & 3.02 & 8.00 & 20.00 & 15.74 & 2.93 \\
\hline HP & 6.00 & 30.00 & 22.87 & 3.92 & 12.00 & 30.00 & 22.85 & 3.67 \\
\hline OP & 6.00 & 30.00 & 17.96 & 4.43 & 7.00 & 26.00 & 16.02 & 3.69 \\
\hline
\end{tabular}

Indicators

Trad $=$ traditionalism

Prog $=$ progressivism

Rom $=$ romanticism

$\mathrm{PC}=$ passion criteria

$\mathrm{HP}=$ harmonious passion

$\mathrm{OP}=$ Obsessive passion

Table 2. Educational beliefs and passion for teaching between pre-service teachers from Malaysia and China.

\begin{tabular}{|c|c|c|c|c|c|c|}
\hline Constructs & Country & Mean & Std. deviation & $t$-value & $p$ & Effect size \\
\hline \multirow[t]{2}{*}{ Trad } & Malaysia & 31.12 & 4.36 & 7.90 & .000 & .130 \\
\hline & China & 27.17 & 3.33 & & & \\
\hline \multirow[t]{2}{*}{ Prog } & Malaysia & 24.38 & 3.23 & 5.98 & .000 & .080 \\
\hline & China & 22.17 & 2.39 & & & \\
\hline \multirow[t]{2}{*}{ Rom } & Malaysia & 27.53 & 4.15 & .31 & .760 & .000 \\
\hline & China & 27.39 & 3.29 & & & \\
\hline \multirow[t]{2}{*}{$\mathrm{PC}$} & Malaysia & 15.70 & 3.02 & -.11 & .910 & .000 \\
\hline & China & 15.74 & 2.93 & & & \\
\hline \multirow[t]{2}{*}{ HP } & Malaysia & 22.87 & 3.92 & .03 & .976 & .000 \\
\hline & China & 22.85 & 3.67 & & & \\
\hline \multirow[t]{2}{*}{ OP } & Malaysia & 17.96 & 4.43 & 3.76 & .000 & .03 \\
\hline & China & 16.02 & 3.69 & & & \\
\hline
\end{tabular}

Indicators
Trad $=$ traditionalism
Prog $=$ progressivism
Rom = romanticism
$\mathrm{PC}=$ passion criteria
$\mathrm{HP}=$ harmonious passion
$\mathrm{OP}=$ Obsessive passion

Table 1 reported the mean and standard deviation for the sub-constructs of educational beliefs and passion for teaching. As 
for educational beliefs, Malaysian pre-service teachers reported the highest mean in traditionalism whereas the Chinese pre-service teachers obtained the highest mean in romanticism. Pre-service teachers of both countries obtained the lowest mean in progressivism which is a sub-construct of educational beliefs. Regarding passion for teaching, Malaysian pre-service teachers and Chinese pre-service teachers scored the highest mean in harmonious passion.

An independent samples t-test was conducted to examine whether there was a significant difference between Malaysia and China pre-service teachers in relation to studied constructs. Table 2 shows the results from t-test analysis by country. As shown in the analysis results, the means of traditionalism and progressivism educational beliefs for both countries were significantly different at $\mathrm{p}=0.00$. Pre-service teachers from Malaysia reported higher mean than those from China in both cases. Hence, this suggests that pre-service teachers from Malaysia hold a more traditional and also progressive educational belief than pre-service teachers from China.

Next, the difference between Malaysian and Chinese pre-service teachers' passion was examined. Results showed that as comparison, obsessive passion among Malaysian pre-service teachers $(\mathrm{M}=17.96, \mathrm{SD}=4.43)$, was higher than in Chinese pre-service teachers $(\mathrm{M}=16.02, \mathrm{SD}=3.96)$. The differences were significant at $\mathrm{t}(407)=3.76, \mathrm{p}=0.00$. This means that Malaysian pre-service teachers were more likely to take teaching as an obsessive passion.

\section{Discussion}

Analysis of the study reported that similarities and differences on educational beliefs and passion for teaching among the Malaysian and Chinese pre-service teachers can be found. As for differences in the aspect of educational beliefs, significant differences were found for traditionalism and progressivism between the pre-service teachers of both countries where Malaysian pre-service teachers reported higher level.

Malaysian pre-service teachers show the highest level in traditionalism whereas the Chinese pre-service scored the highest in romanticism. This finding illustrated that the pre-service teachers in Malaysia are found to be more "traditional" where traditional pedagogy will be their priority in transmitting knowledge to students. This means the Malaysian pre-service teachers will serve as the source of knowledge while learners serve as passive receivers (Kuzu, 2007) which matches the characteristics of teacher-centered approach with highly "teacher-dominated interaction"(Broughton et al., 1994).

Instead, the findings demonstrated that the majority of Chinese pre-service teachers' hold beliefs in romanticism. Chinese pre-service teachers are more incline to believe that students who failed to show good achievement in school have the potential to perform much better. They also feel that students' academic achievement is heavily depends on the opportunities provided to them and not so much of innate intellectual limits (Murray, 2008). However, this is not seen to be agreed by few studies conducted on Chinese pre-service and in service teachers.

Yang and Leung (2015) reported that Chinese pre-service mathematics teachers tend to have higher level of constructivist beliefs than traditional beliefs in mathematics teaching and learning. Another study by Sang, Valcke, Tondeur, Zhu, and Van Braak (2012) to explore the educational belief of primary education Chinese student teachers found that first year pre-service teachers hold stronger constructivist beliefs as compared to senior pre-service

teachers. This is supported by the findings of Deng, Chai, Tsai, and Lee (2014) which discovered Chinese pre-service and in-service teachers tend to be engaged in constructivist teaching rather than traditional teaching perhaps due to the explicit promotion of the constructivist pedagogy in recent years in China.

The findings of this study have revealed that Malaysian and Chinese pre-service teachers hold different educational beliefs in carrying out their duties as educators. According to Charalambos et al. (2008) and Cross (2009), belief is normally understood as a multifaceted construct and teachers will have different types of beliefs. But the point to be high- 
lighted is that, as explained by Kagan (1992), beliefs held by teachers are very vital because they often unconsciously influence the teachers' assumptions about students, classrooms, and the academic material to be taught. This is supported by Walkington (2005) who stated that the core beliefs and perception of teaching might impact the process of learning to teach and developing concepts of teaching among pre-service teachers. In spite of that, attention needs to be drawn to the findings that pre-service teachers of both Malaysia and China are low in the beliefs of progressivism as compared to traditionalism and romanticism. This may be attributed to advancement in new technology in education, hence thrusting constructivism in the spotlight. Constructivism has a complementary relationship with technology; both benefit each other (Nanjappa, Aloka, \& Grant, 2003). Constructivism gets its roots in progressivism.

As for passion for teaching, significant differences have been reported for obsessive passion between the Malaysian and Chinese pre-service teachers where Malaysian pre-service teachers reported higher level of obsessive passion. Although there is no significant difference revealed on harmonious passion between Malaysian and Chinese pre-service teachers, both countries reported the highest level for this passion. This is aligned with the findings of Kim (2013) who stated that the childhood pre-service teachers obtained high mean scores on harmonious passion as compared with obsessive passion, implying that they were developing adaptive outcomes for their future success as professional teachers.

Harmonious passion is one of the factors that can affect teachers' teaching life. Research has proven that this passion is always related to positive psychological well-being. For instance, increase in harmonious passion for teaching anticipates increase in work satisfaction but decrease in burnout (Carbonneau et al., 2008). According to Carbonneau et al. (2008), harmonious passion was found to have positive relationship with work satisfaction and perceived positive student behaviors. Adding to that, Moe (2016) also reported a relationship between harmonious passion and job satisfaction, and self-efficacy.

The findings further illustrated that Malaysian pre-service teachers possess higher level of obsessive passion than Chinese pre-service teachers. Carbonneau et al. (2008) explained that if teachers hold obsessive passion, they are controlled by their activity; they have no choice but to do it. Earlier studies have reported that obsessive passion is related to maladaptive outcomes namely, negative emotion after and during doing the passionate activities (Vallerand et al., 2003) reduced work satisfaction (Vallerand \& Houlfort, 2003), conflicts in life (Vallerand et al., 2003; Seguin-Levesque et al., 2003).

The study has demonstrated that pre-service teachers of both countries reported differences and similarities of educational beliefs and passion for teaching which might have been contributed by many factors. Background of the pre-service teachers such as experiences during their schooling determined their beliefs about teaching and learning (Kagan, 1992; Tatto, 1998; Lortie, 1975). According to OECD (2009), teachers' beliefs are formed relatively early during the initial education or before and it remain stable over time, it is quite difficult to change as psychology finding noted that attitude can be resistance to change. This is supported by Clark (1988) whom defined educational beliefs as "predetermined concepts" which formed from one's personal experiences, beliefs, and values. This educational belief was formed before an individual enrolled into an education major or before they involved in teaching practices. Passion for teaching is usually related to reasons for selecting teaching as profession and basically it is contributed by extrinsic, intrinsic and altruistic motivation (Watt et al., 2012). Passion for teaching can be contributed by can be influence by the environment of the school. As explained by Kim (2013), pre-service teachers need conducive surrounding where they are exposed to many opportunities for making networking for they to gain support from colleagues and share experience in order to sustain their passion. Passion may grow or diminish according to personal and social circumstances too (Day, 2009).

As pre-service teachers are the educators of the future generation, the findings of the study make a vital contribution especially to teacher education program providers of both countries. Pre-service teachers of both countries scored the low- 
est for progressivism but the highest in traditionalism and this finding should draw the attention of teacher education program providers. Program providers have to consider if future educators with traditional beliefs are suitable to produce a generation able to face the challenges of the rapid changing world. Consideration is needed on whether this type of future educator is capable in producing the next generation who are innovative and creative with higher order thinking skills.

It is fortunate for Malaysia and China to have future educators with high score for harmonious passion. This is because a number of positive outcomes to harmonious passion have been reported by previous research. Harmonious passion is found to be positively correlated with flow, which in turn is negatively associated with burnout (Lavigne, Forest, \& Crevier-Braud, 2012); individual with harmonious passion tend to have positive emotion but few negative one (Mageau et al., 2005), commit to activities aligned with their other goals and needs (Thorgren \& Wincent, 2013), will not neglect alternative goals (Bélanger et al., 2013). Furthermore, harmonious passion leans to foster creativity (Liu, Chen, \& Yao 2011).

Another point to highlight about passion is that Malaysian pre-service teachers were found to have higher obsessive passion than their Chinese counterparts. This finding needs to be addressed with much caution as they are the pre-service teachers, will the obsessive passion level increase when they become teachers? If so, what is the impact on our next generation? Studies showed that obsessive passion will cause individual experience internal pressure to accomplish an assignment and to rigid determination which may further avert well-being (Vallerand et al., 2003). Obsessive passion is found to be unrelated to creativity which is the important characteristic that makes a successful teacher. Individuals with obsessive passion tend to inclined to neglect alternatives goals (Bélanger et al., 2013).

The findings of this study have generated crucial inputs that need to be considered by various stakeholders especially teacher education program providers in both countries. The quality of our next generation depends heavily on the quality of teachers. The pre-service teachers are the going-to-be teachers; thus it is necessary to ensure that they hold educational belief and passion for teaching which can enable them to develop the young generation ready for challenges in the rapidly changing world.

\section{References}

Andrew, M. D., \& Richard, L. S. (1995). Has Reform in Teacher Education Influenced Teacher Performance? An Outcome Assessment of Graduates of an Eleven-University Consortium. Action in Teacher Education, 17(3), 43-53. https://doi.org/10.1080/01626620.1995.10463255.

Bélanger, J. J., Marc-André, K., Lafrenière, R. J. V., \& Arie W. K. (2013). When Passion Makes the Heart Grow Colder: The Role of Passion in Alternative Goal Suppression. Journal of Personality and Social Psychology, 104 (1), 126-47. https://doi.org/10.1037/a0029679.

Bents, M., \& Bents, R. (1990). Perceptions of Good Teaching among Novice, Advanced Beginner and Expert Teachers. In . Boston.

Boumová, V. (2008). Traditional vs. Modern Teaching Methods: Advantages and Disadvantages of Each. Diplomová práce, Masaryk University, Faculty of Arts.

Broughton, G., Brumfit, C., Flavell, R., Pincas, A., \& Hill, P. (1994). Teaching English as a Foreign Language. Second. London: Routledge.

Carbonneau, N., Robert, V., Claude, F., \& Frederic, G. (2008). The Role of Passion for Teaching in Intrapersonal and Interpersonal Outcomes. Journal of Educational Psychology - J EDUC PSYCHOL 100 (November). https://doi.org/10.1037/a0012545.

Charalambous, C. Y., George, N. P., \& Leonidas, K. (2008). Tracing the Development of Preservice Teachers' Efficacy Beliefs in Teaching Mathematics during Fieldwork. Educational Studies in Mathematics, 67(2), 125-42. https://doi.org/10.1007/s10649-007-9084-2.

Clark, C. M. (1988). Asking the Right Questions about Teacher Preparation: Contributions of Research on Teacher Thinking. Educational Researcher, 17(2), 5-12. https://doi.org/10.3102/0013189X017002005.

Cross, D. I. (2009). Alignment, Cohesion, and Change: Examining Mathematics Teachers' Belief Structures and Their Influence on Instructional Practices. Journal of Mathematics Teacher Education, 12(5), 325-346. https://doi.org/10.1007/s 10857-009-9120-5.

Day, C. (2009). A Passion for Quality: Teachers Who Make A Difference. Tijdschrift Voor Lerarenopleiders 30 (3).

Deng, F., Ching, S. C., Chin-Chung, T., \& Min-Hsien, L. (2014). The Relationships among Chinese Practicing Teachers’ Epistemic Beliefs, 
Pedagogical Beliefs and Their Beliefs about the Use of ICT. Journal of Educational Technology \& Society, 17(2), $245-256$.

"Education for All.” (2016). Education International. https://www.ei-ie.org/en/websections/content_detail/3273.

Fernet, C., Geneviève, L. L., Robert, J. V., \& Stéphanie, A. (2014). Fired up with Passion: Investigating How Job Autonomy and Passion Predict Burnout at Career Start in Teachers. Work \& Stress 28 (3), 270-288. https://doi.org/10.1080/02678373.2014.935524.

Fried, R. L. (2001). The Passionate Teacher: A Practical Guide (2nd Edition). Second. Boston: Beacon Press.

Hinton, P. R., Brownlow, C., McMurray, I., \& Cozens, B. (2004). SPSS Explained. London, UK: Routledge.

Kagan, D. M. (1992). Implication of Research on Teacher Belief. Educational Psychologist, 27(1), 65-90. https://doi.org/10.1207/s15326985ep2701_6.

Kim, H. (2013). Passion on Teaching Beliefs and Efficacy. Academic Exchange Quarterly, 17(4), $20-27$.

Kuzu, A. (2007). Views of Pre-Service Teachers on Blog Use for Instruction and Social Interaction. The Turkish Online Journal of Distance Education, 8 (3).

Labaree, D. F. 2005. Progressivism, Schools and Schools of Education: An American Romance. Paedagogica Historica: International Journal of the History of Education, 41 (February), 275-288. https://doi.org/10.1080/0030923042000335583.

Lavigne, G. L., Jacques, F., \& Laurence, Crevier-B. (2012). Passion at Work and Burnout: A Two-Study Test of the Mediating Role of Flow Experiences. European Journal of Work and Organizational Psychology, 21(4), 518-546. https://doi.org/10.1080/1359432X.2011.578390.

Lin, R., Xie, J., Jeng, Yoau-C., \& Huang, S. (2010). The Relationship between Teacher Quality and Teaching Effectiveness Perceived by Students from Industrial Vocational High Schools. 1(2), 167-187.

Liu, D., Xiao-Ping, C., \& Xin, Y. (2011). From Autonomy to Creativity: A Multilevel Investigation of the Mediating Role of Harmonious Passion. The Journal of Applied Psychology, 96(2), 294-309. https://doi.org/10.1037/a0021294.

Lortie, D. C. (1975). Schoolteacher: A Sociological Study. Chicago: The University of Chicago Press.

Mageau, G. A., Robert, J. V., Françlois, L. R., Catherine, F. R., \& Pierre, J. P. (2005). Passion and Gambling: Investigating the Divergent Affective and Cognitive Consequences of Gambling1. Journal of Applied Social Psychology, 35(1), 100-118. https://doi.org/10.1111/j.1559-1816.2005.tb02095.x.

Mart, C. T. (2013). A Passionate Teacher: Teacher Commitment and Dedication to Student Learning. International Journal of Academic Research in Progressive Education and Development, 2(1), 437-442.

Moè, A. (2016). Harmonious Passion and Its Relationship with Teacher Well-Being. Teaching and Teacher Education, 59(October), 431-437. https://doi.org/10.1016/j.tate.2016.07.017.

Murray, C. (2008). The Age of Educational Romanticism. The New Criterion, 26 (9).

Nanjappa, A., \& Michael, G. (2003). Constructing on Constructivism: The Role of Technology. Electronic Journal for the Integration of Technology in Education, 2 (January).

Noddings, N. (2007). Philosophy of Education. Second. Colorado, CA: Westview Press.

OECD. (2009). Creating Effective Teaching and Learning Environments. TALIS. OECD Publishing. https://doi.org/10.1787/9789264068780-en.

Sang, G., Martin, V., Jo, T., Zhu, C., \& Johan, van-B. (2012). Exploring the Educational Beliefs of Primary Education Student Teachers in the Chinese Context. Asia Pacifica Education Review, 13(3), 417-425. http://dx.doi.org/10.1007/s 12564-012-9206-0.

Seguin-Levesque, C., Marie, L. N., Lalibertea, L. G., Pelletier, C. B., \& Robert, J. V. (2003). Harmonious and Obsessive Passion for the Internet: Their Associations With the Couple's Relationship1. Journal of Applied Social Psychology, 33(1), 197-221. https://doi.org/10.1111/j.1559-1816.2003.tb02079.x.

Silvernail, D. L. (1992). The Development and Factor Structure of the Educational Beliefs Questionnaire. Educational and Psychological Measurement, 52(3), 663-667. https://doi.org/10.1177/0013164492052003015.

Su, Y. (2012). Teach to Live or Live to Teach: A Case Study on the Educational Beliefs of Displaced Teachers in Taiwan. International Journal of Research Studies in Education, 1(1), 3-20. https://doi.org/10.5861/ijrse.2012.v1i1.2.

Tatto, M. T. (1998). The Influence of Teacher Education on Teachers' Beliefs about Purposes of Education, Roles, and Practice. Journal of Teacher Education, 49(1), 66-77. https://doi.org/10.1177/0022487198049001008.

Thorgren, S., \& Joakim, W. (2013). Passion and Role Opportunity Search: Interfering Effects of Conflicts and Overloads. International Journal of Stress Management, 20(February), 20. https://doi.org/10.1037/a0031457.

Vallerand, R. J., \& Houlfort, N. (2003). Passion at Work: Toward a New Conceptualization. In Social Issues in Management, 3,175-204. Emerging Perspectives of Values in Organizations. Greenwich, CT: Information Age.

Vallerand, R. J., Celine, B., Genevieve, A. M., Richard, K., Catherine, R., Maude, L., Marylene, G., \& Josee, M. (2003). Les Passions de l'ame: On Obsessive and Harmonious Passion. Journal of Personality and Social Psychology, 85(4), $756-67$. https://doi.org/10.1037/0022-3514.85.4.756. 
Vallerand, R. J., Yvan, P., Frederick, L. P., \& Julie, C. (2010). On the Role of Passion for Work in Burnout: A Process Model. Journal of Personality, 78(1), 289-312. https://doi.org/10.1111/j.1467-6494.2009.00616.x.

Villarroel, G. (2015). How Passion Can Make the Difference in the Classroom. http://www.usma.edu/cfe/Literature/Villarroel_15.pdf.

Walkington, J. (2005). Becoming a Teacher: Encouraging Development of Teacher Identity through Reflective Practice. Asia-Pacific Journal of Teacher Education, 33(March). https://doi.org/10.1080/1359866052000341124.

Watt, H. M. G., Paul, W. R., Uta, K., Mareike, K., Beate, B., Ulrich, T., \& Jürgen, B. (2012). Motivations for Choosing Teaching as a Career: An International Comparison Using the FIT-Choice Scale. Teaching and Teacher Education, 28(6), 791-805. https://doi.org/10.1016/j.tate.2012.03.003.

Yang, X., \& Frederick, K. S. L. (2015). The Relationships among Pre-Service Mathematics Teachers' Beliefs about Mathematics, Mathematics Teaching, and Use of Technology in China. EURASIA Journal of Mathematics, Science \& Technology Education, 11(6), $1363-1378$. https://doi.org/10.12973/eurasia.2015.1393a.

Yero, J. L. (2002). Teaching in Mind : How Teacher Thinking Shapes Education. Hamilton: MindFlight Publishing. 